\title{
A NEW POLYVINYL POLYMER SPRAY ADDITIVE FOR DRIFT CONTROL
}

\author{
B. N. MacDIARMID
}

Ivon Watkins-Dow Ltd, New Plymouth.

Summary

A polyvinyl polymer spray additive was found to increase the stability and size of spray droplets, without appreciably altering the viscosity of the spray solution. In field trials, the polymer decreased the drift of agricultural sprays applied by ground equipment by more than $90 \%$ without affecting the nozzle output or markedly affecting the droplet spectrum. Crop selectivity and performance trials indicated that the polymer has only minor effects on the weed and crop activity of herbicides. The physical properties, ease of mixing and low rates (30 to $60 \mathrm{ml} / 100$ litres) required for effectiveness make the polymer a very suitable additive for reducing pesticide spray drift.

\section{INTRODUCTION}

The damage which may be caused by herbicide spray drift is well recognised in the agricultural chemical industry (May, 1966).

Spray drift is primarily a function of droplet size, although wind speed and release height influence the degree and extent of the drift (Yates and Hager, 1970). The smaller the droplet size, the more liable they are to drift.

The generation of small droplets in a spray stream may be overcome in a number of ways:

(a) Mechanically, either by increasing the nozzle size or decreasing the pump pressure; or by using special application equipment.

(b) Chemically, by an additive which changes the physical properties of the spray solution.

(c) By a combination of (a) and (b), such as that employed in the invert emulsion system (May, 1966).

The system involving the least amount of effort to the operator is the spray additive, which is incorporated in the spray mixture when drift control is required. A number of additives are available but because they increase the viscosity of the spray solution considerably (Suggitt, 1965; Johnson et al., 1974) they are only' suitable for aerial application, which allows time for the spray stream to disintegrate. High costs, chemical shortages and mixing difficulties have prevented their widespread acceptance in New Zealand.

The need, therefore, for a suitable drift control system prompted this evaluation of a promising new polyvinyl polymer spray additive LO-DRIFT supplied by Amchem Products Inc. and reported by Johnson et al (1974).

\section{Field Trials}

\section{EXPERIMENTAL METHODS}

These were conducted with an Oxford Precision Sprayer fitted with a $2 \mathrm{~m}$ boom and SS 8003 fan nozzles. Dye was added to the spray solu- 


\section{New Products}

tions which were applied at 250 litres/ha to pasture at $200 \mathrm{kPa}$ from $50 \mathrm{~cm}$. The spray pattern and drift was recorded with Kromekote dye sensitive cards (after Bouse, 1969) placed at 1,2,3,5,7 and $10 \mathrm{~m}$ from the spray swath. A binocular microscope, with graduated dots on the eye-piece was used to measure the droplet spectrum of spray drift recorded on the cards (see Butler et al 1969 for details).

A $5 \mathrm{~m}$ spray boom with various nozzles was used to determine the effect of the polymer on nozzle output. Dye sensitive cards and herbicide phytotoxicity trials were used to study the effect of the polymer on nozzle pattern.

\section{Laboratory}

Dye solutions of $320 \mathrm{ml}$ were mixed for one minute in a beaker with a laboratory stirrer. These solutions were then sprayed at Kromekote cards using a $500 \mathrm{ml}$ pistol-type hand applicator with a variable solid cone jet. The cards, $8 \mathrm{~cm}$ wide, $10 \mathrm{~cm}$ high were held vertically $30 \mathrm{~cm}$ from the sprayer and were spaced $3 \mathrm{~cm}$ apart to allow the main jet of spray to pass between them. The additions of polymer and/or surfactant were continued until the spray scatter was reduced to a set of 'standard' cards known to represent drift reduction in the field. The herbicide concentrations used were those commonly employed in the field. A fresh mixture of each herbicide/additive combination was made.

\section{Field Trials - Spray Drift}

\section{RESULTS AND CONCLUSIONS}

Table 1 shows the dramatic reduction at all stations in the number of droplets which were recorded downwind of the spray swath when the polymer was added to the spray solution. The windspeed was $13 \mathrm{~km} / \mathrm{h}$ The results agree with a $91 \%$ reduction found by Butler and Goering (1974) in almost identical tests. When the minimum recommended rate was doubled, virtually all spray drift was eliminated.

TABLE 1: SPRAY DRIFT NUMBER OF DROPLETS $/ \mathrm{cm}^{2}$ (4 CARDS, 6 AREAS/CARD)

\begin{tabular}{|c|c|c|c|c|c|c|c|c|}
\hline \multirow[b]{2}{*}{ 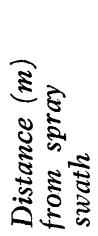 } & \multicolumn{7}{|c|}{ Polymer Solutions } & \multirow[b]{2}{*}{ 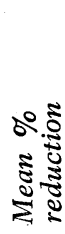 } \\
\hline & 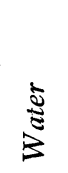 & 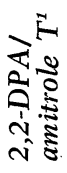 & 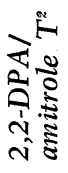 & 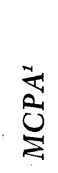 & 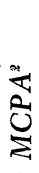 & 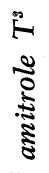 & 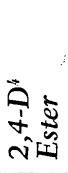 & \\
\hline $\begin{array}{r}1 \\
2 \\
3 \\
5 \\
7 \\
10\end{array}$ & $\begin{array}{r}404 \\
173 \\
142 \\
50 \\
32 \\
23\end{array}$ & $\begin{array}{r}40 \\
7 \\
6 \\
2 \\
2 \\
0\end{array}$ & $\begin{array}{l}5 \\
0 \\
0 \\
0 \\
0 \\
0\end{array}$ & $\begin{array}{r}44 \\
9 \\
11 \\
4 \\
9 \\
3\end{array}$ & $\begin{array}{l}0 \\
0 \\
0 \\
0 \\
0 \\
0\end{array}$ & $\begin{array}{r}27 \\
29 \\
5 \\
4 \\
7 \\
2\end{array}$ & $\begin{array}{r}26 \\
17 \\
28 \\
7 \\
8 \\
3\end{array}$ & $\begin{array}{l}94 \\
94 \\
92 \\
94 \\
86 \\
94\end{array}$ \\
\hline
\end{tabular}

$1=$ Herbicide + polymer $1: 3200$

${ }^{2}=$ Herbicide + polymer 1:1600 (double minimum rate)

${ }^{3}=$ Herbicide + surfactant $1: 1600+$ polymer $1: 3200$

${ }^{4}=$ Herbicide + surfactant 1:1600 + polymer 1:1600

The results in Table 2 show that there was no major change in the droplet spectrum of the spray drift when the polymer was added. The proportion of small droplets $(<100 \mu)$ was similar, but there were more large $(>250 \mu)$ droplets with the polymer and less in the 100-250 
$\mu$ range. These results suggest that the polymer acts by increasing the shear strength of the spray solution. This causes a reduction in the proportion of the spray stream which is shattered by the edges of the nozzle and therefore liable to drift from the target area. This effect can be seen in the spray patterns in Figure 1.

TABLE 2: DROPLET SPECTRUM OF SPRAY DRIFT (\% TOTAL NUMBER OF DROPLETS)

\begin{tabular}{lcccccccc}
\hline Droplet & & \multicolumn{8}{c}{ Distance from Spray Swath $(m)$} & Mean \\
Range & & 1 & 2 & 3 & 5 & 7 & 10 & $\%$ \\
\hline$<100 \mu$ & Water & 34 & 41 & 37 & 49 & 49 & 56 & 44 \\
& Polymer* & 34 & 47 & 42 & 41 & 50 & 46 & 44 \\
$100-250 \mu$ & Water & 38 & 39 & 45 & 40 & 35 & 32 & 38 \\
& Polymer* & 38 & 26 & 22 & 18 & 27 & 23 & 26 \\
$>250 \mu$ & Water & 28 & 20 & 18 & 11 & 16 & 12 & 18 \\
& Polymer* & 25 & 27 & 36 & 23 & 23 & 31 & 30 \\
\hline
\end{tabular}

* Using amitrole T 1:50 plus surfactant 1:1600 plus polymer 1:3200

Nozzle Performance

Table 3 shows that the addition of the polymer did not greatly affect the output of fan or disc and core nozzles. The width of the spray pattern however, was reduced up to $30 \%$, depending on the amount of polymer added and the nozzle type. This effect was overcome in the field by raising the boom until the desired overlap was achieved. If a thicker polymer solution was made, the spraying pressure had to be raised by up to $75 \mathrm{kPa}$ also.

TABLE 3: NOZZLE OUTPUT AND PATTERN WIDTH OF POLYMER SPRAY SOLUTIONS

\begin{tabular}{|c|c|c|c|c|c|c|c|}
\hline $\begin{array}{l}\text { Nozzle } \\
\text { Type }\end{array}$ & $\begin{array}{l}\text { Theoretica } \\
\text { Output } \\
\text { (from manu } \\
\text { litres/min }\end{array}$ & $\begin{array}{l}\text { ual) Water } \\
n \text { litres } / \text { min }\end{array}$ & $\begin{array}{c}\text { Nozzle Outp } \\
\text { Polymer } \\
\text { 1:3200 } \\
\text { n litres } / \text { min }\end{array}$ & $\begin{array}{l}\text { put } \\
\text { Polymer } \\
1: 1600 \\
\text { litres/min }\end{array}$ & $\begin{array}{l}{ }^{* P a t} \\
\text { Water } \\
\text { cm }\end{array}$ & $\begin{array}{c}\text { ttern Wid } \\
\text { Polymer } \\
1: 3200 \\
\mathrm{~cm}\end{array}$ & $\begin{array}{l}\text { dth } \\
\text { Polymer } \\
1: 1600 \\
\mathrm{~cm}\end{array}$ \\
\hline $\begin{array}{c}\text { TeeJet } \\
730231 \\
730308 \\
8002 \\
8003\end{array}$ & $\begin{array}{c}\text { (Spraying S } \\
0.76 \\
1.02 \\
0.64 \\
0.98\end{array}$ & $\begin{array}{c}\text { Systems)@ @ } \\
0.73 \\
1.00 \\
0.66 \\
1.04\end{array}$ & $\begin{array}{c}200 \mathrm{kPa} \\
0.63 \\
1.04 \\
0.69 \\
1.05\end{array}$ & $\begin{array}{l}0.69 \\
0.98 \\
0.67 \\
1.05\end{array}$ & $\begin{array}{l}52 \\
44 \\
54 \\
52\end{array}$ & $\begin{array}{l}37 \\
24 \\
39 \\
39\end{array}$ & $\begin{array}{l}34 \\
20 \\
37 \\
34\end{array}$ \\
\hline $\begin{array}{c}\text { TeeJet @ } \\
730308 \\
8002\end{array}$ & @ $\begin{array}{c}275 \mathrm{kPa} \\
1.16 \\
0.76\end{array}$ & $\begin{array}{l}1.14 \\
0.77\end{array}$ & 二 & $\begin{array}{l}1.14 \\
0.82\end{array}$ & $\begin{array}{c}44 \\
54\end{array}$ & $\begin{array}{l}29 \\
42\end{array}$ & $\begin{array}{l}27 \\
44\end{array}$ \\
\hline $\begin{array}{c}\text { Disc and } \\
\text { D3-25 } \\
\text { D4-45 }\end{array}$ & $\begin{array}{c}\text { d Core @ } \\
0.64 \\
1.18\end{array}$ & $\begin{array}{r}200 \mathrm{kPa} \\
0.82 \\
-\end{array}$ & $\begin{array}{l}0.73 \\
1.24\end{array}$ & $\begin{array}{r}0.82 \\
-\end{array}$ & $\begin{array}{l}49 \\
47\end{array}$ & $\begin{array}{l}34 \\
37\end{array}$ & 二 \\
\hline
\end{tabular}

* Using amitrole T 1:50 plus surfactant 1:1600 \pm polymer. Mean of 3 nozzles, $35 \mathrm{~cm}$ from ground.

Phytotoxicity

The polymer on its own is non-phytotoxic to crops. When used in trials with dinoseb and MCPB on pea crops; with MCPB on lucerne; 


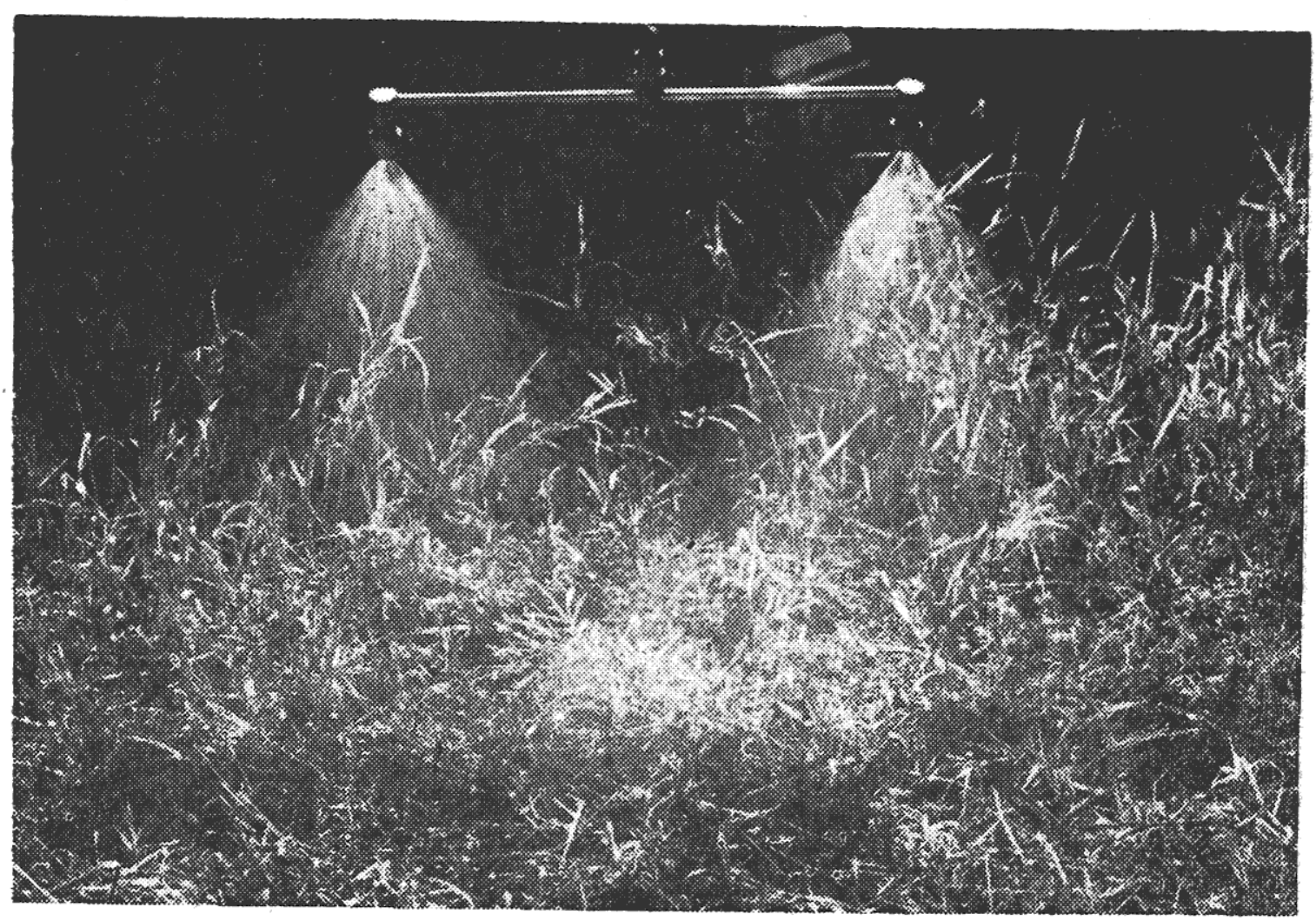

Fig. 1 (a) S.S. 730231 Nozzle at $200 \mathrm{kPs}$ without Lo-Drift

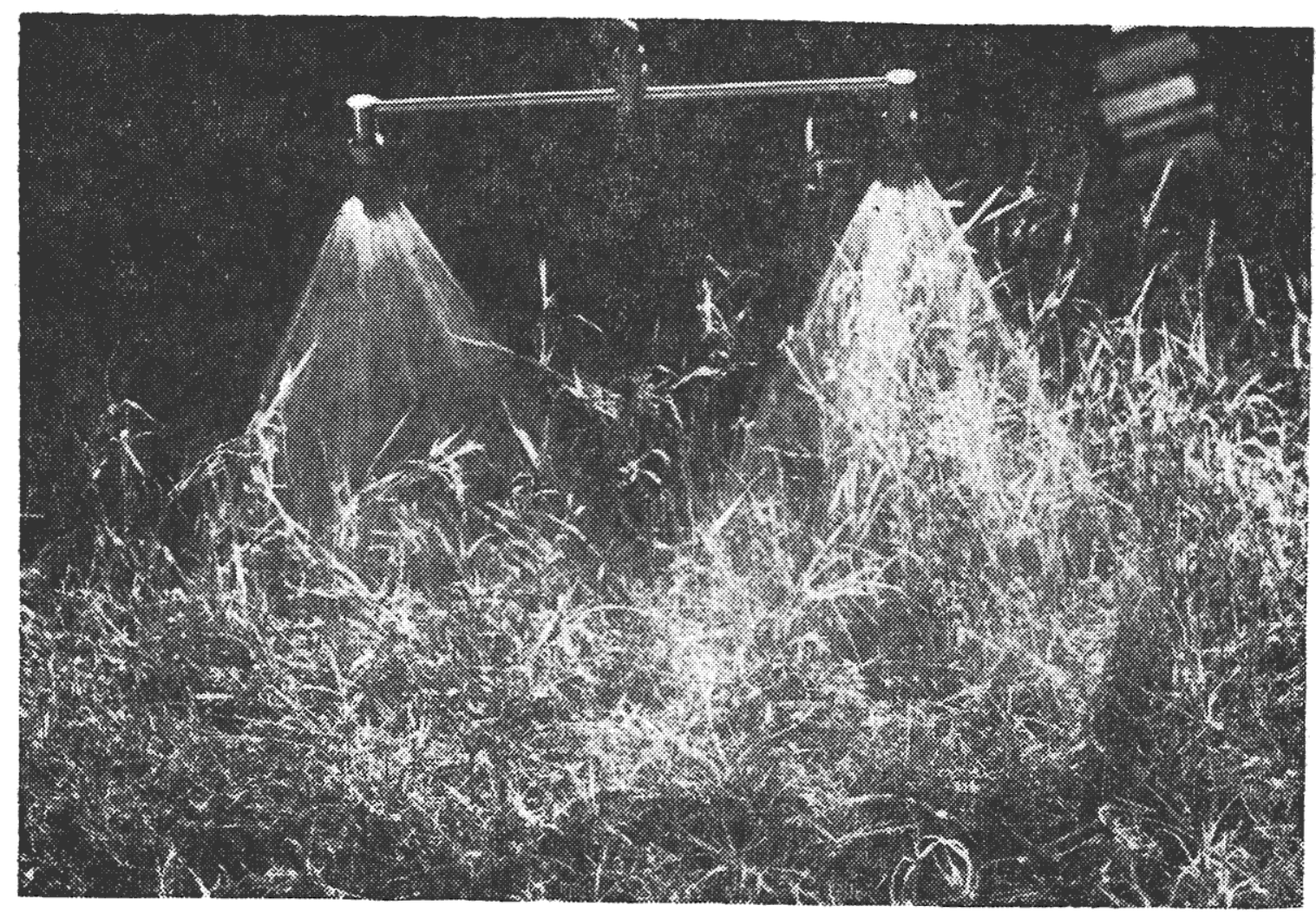

Fig. 1 (b) S.S. 730231 Nozzle at $200 \mathrm{kPs}$ with Lo-Drift 
with MCPA/dicamba, MCPA/bromoxynil and 2,4-D on wheat; and nitrofen/picloram on brassicas, no additional injury was observed from the spray solutions containing the polymer (details available). Johnson et al (1974) also observed no injury on peas from the polymer. No differences in weed control was observed in either study.

Laboratory Tests

In all, over 200 spray solutions with the polymer, including 37 pesticide formulations, were tested with the laboratory method. The polymer was found to be insoluble in water and a surfactant, either in the pesticide formulation or as an addition to the spray solution, was required to disperse it. The greater the concentration of pesticide, the less the requirement for additional surfactant. Apart from requiring a surfactant, the polymer was compatible with all the pesticides tested, regardless of the sequence of addition of the spray components. The results indicated that the herbicide formulations fell essentially into three main groups, set out below. Each group is the minimum concentration of polymer with or without a non-ionic surfactant, which was required to achieve the 'standard' spray pattern.

\section{Group I}

Add $30 \mathrm{ml}$ of polymer/100 litres of spray solution. Included 21 formulations e.g. MCPA, amine salt of 2,4-D, methylarsinic acid, 2,2-DPA, dinoseb and thiophanate-methyl.

\section{Group 2}

Add $30 \mathrm{ml}$ of polymer $+60 \mathrm{ml}$ surfactant/100 litres of spray solution. Included nine formulations e.g. amitrole $\mathrm{T}$, simazine wettable powder and atrazine oil suspension.

Group 3

Add $60 \mathrm{ml}$ of polymer $+60 \mathrm{ml}$ surfactant $/ 100$ litres of spray solution. Included seven formulations e.g. butyl ester of $2,4-\mathrm{D}$, butyl ester of 2,4,5-T and bromoxynil octanoate.

These groups indicate that the polymer solutions perform best in the presence of formulations of water soluble salts containing relatively large amounts of surfactants and solvents. The more insoluble salts as wettable powders (or as aqueous or oil suspensions) require additional surfactant, while the oil soluble chemicals as emulsifiable concentrates require additional polymer as well as additional surfactant. When used in herbicide mixtures, it was found that the effectiveness of the polymer was usually enhanced by the addition of a herbicide with which it combines readily e.g. MCPA to bromoxynil octanoate.

If the rate of the polymer was doubled i.e. 30 to $60 \mathrm{ml} / 100$ litres in Group 1 and 2 and 60 to $120 \mathrm{ml} / 100$ litres in Group 3, a 'thicker' spray solution results. These solutions, which reduced spray drift by up to $100 \%$ (Table 1) are particularly useful for gun application of nonselective sprays and for hormones in hazardous areas. However, because the spray droplet size increased appreciably with these 'thicker' solutions, they were not suitable for spraying selective herbicides, fungicides or insecticides.

\section{Physical properties}

The polymer solutions needed vigorous agitation for at least five minutes before spraying. If agitation continued for more than one hour the drift-reducing properties of the solution were sometimes reduced. However, it could be rectified by the addition of further polymer. In comparison with hydroxyethylcellulose, the polymer had no appreciable effect on the viscosity of the spray solution, as shown in Table 4 .

175 . 
New Products

TABLE 4: FLOW RATES OF SPRAY SOLUTIONS (NUMBER 4 FORD CUP)

\begin{tabular}{cccr}
\hline polymer & & \multicolumn{2}{c}{ hydroxyethylcellulose } \\
ml/100 litres & secs & $\mathrm{g} / 100$ litres & \multicolumn{1}{c}{ secs } \\
\hline 0 & 11 & 0 & 11 \\
30 & 12 & 300 & 13 \\
60 & 12 & 500 & 15 \\
120 & 13 & 1000 & 60 \\
240 & 14 & 2000 & $>1000$ \\
\hline
\end{tabular}

The polymer formulation is a non-toxic, odourless, milky-coloured liquid. It can be very slippery if spilt on the outside of containers and the label precautions should be observed.

\section{Aerial Studies}

No spray drift measurements have been made with aerial applications yet. However, photographic studies of polymer solutions applied from a helicopter show a significant reduction in the spray 'whorl' created by the rotors at the edge of the spray pattern. No differences in weed control (thistles, barley grass) have been observed (Woon, pers. comm.). The rates of polymer may be increased for aerial applications because of the larger nozzles employed and the shear forces involved in the spray stream. Johnson et al (1974) recommends removing the whirl plates in D4, D6 or D8 jet nozzles and pointing the nozzles straight back for maximum drift control

\section{ACKNOWLEDGEMENTS}

I am grateful to my technician, J. Ballinger and other staff of the Research Division, Ivon Watkins-Dow for their assistance.

\section{REFERENCES}

Bouse, L. F., 1969. Aerial spray penetration through foliage canopies. Trans. Amer. Soc. Agric. Eng.: 12:86.

Butler B. J. and Goering, C. E., 1974. Field studies of conventional methods vs thickening agents for drift control. Proc. Oklahoma State Univ. Agric. Chem. Conf.: 12.

Butler, B. J., Akesson, N. B. and Yates, W. E., 1969. Use of spray adjuvants to reduce drift. Trans. Amer. Soc. Agric. Eng.: 12:182.

Johnson, R. R., Fosse, R. A. and Dunster, K. W., 1974. Progress report on crop tolerance, weed control and drift control with LO-DRIFT spray additive. Proc. West. Soc. Weed Science, 1974 (in publication).

May, E. B., 1966. The Biflon System. Proc. 19th N.Z. Weed and Pest Control Conf.: 276.

Suggitt, J. W., 1965. Hydroxyethylcellulose thickening of herbicides for spray drift control. Ont. Hydro. Res. $Q$ (3rd q.): 5.

Yates, W. E., and Hager, J., 1970. Evaluation of aircraft spray techniques. Proc. 23rd N.Z. Weed and Pest Control Conf.: 127.

Proc. 27th N.Z. Weed and Pest Control Conf. 